\title{
Preliminary investigation of the materials and techniques used in a decorated wooden stick of king Tutankhamun
}

\author{
Ahmed Abdrabou ${ }^{1, *}$ (D) Medhat Abdallah'1 , Eman Nabil ${ }^{2}$, Yasunari Matsuda ${ }^{3}$, \\ Hussein M. Kamal ${ }^{1}$
}

${ }^{1}$ Grand Egyptian Museum-Conservation Centre, Remaya square, Giza, Egypt

${ }^{2}$ Khufu Boat Museum, Archaeological Pyramids Area, Giza, Egypt

${ }^{3}$ Toyo institute of Art and Design, 2-6 Tomihisa-cho, Shinjuku, Tokyo, Japan

*ahmed_abdrabou87@yahoo.com

\begin{abstract}
The focus of this work is to shed more light on materials and decorating techniques used on a decorated wooden stick of king Tutankhamun. Moreover, the authors were interested in using a developed methodology to unfold the cylindrical decorations of the stick. The botanical species of the wood and bark samples were identified by observing thin sections under an optical transmission light microscope; the decorating materials layered on the wood surface were analyzed by scientific and analytical techniques including optical microscopy (OM), environmental scanning electron microscopy (ESEM), X-ray fluorescence spectroscopy (XRF), X-ray diffraction (XRD) and Fourier transform infrared spectroscopy (FTIR). The analyses provided new information concerning the materials and decorating techniques that varied from top to bottom of the same stick. The characterization of this stick represents a first step in determining the materials and decorating techniques used to produce this particular kind of sticks during king's Tutankhamun period.
\end{abstract}

Investigação preliminar de materiais e técnicas usadas num

bastão de madeira decorado do rei Tutankhamon

\section{Resumo}

Este trabalho teve como objectivo aprofundar o conhecimento sobre materiais e técnicas decorativas empregues num bastão de madeira decorado do rei Tutankhamon. Além disso, os autores estiveram interessados em usar uma metodologia desenvolvida para visualizar as decorações cilíndricas do bastão. As espécies botânicas de amostras da madeira e da casca foram identificadas pela observação de lâminas delgadas num microscópio óptico de luz transmitida; os materiais de decoração dispostos em camadas sobre a superfície de madeira foram analisados por técnicas analíticas e científicas incluindo microscopia óptica (OM), microscopia electrónica de varrimento ambiental (ESEM), espectroscopia de fluorescência de raios X (XRF), difracção de raios $X(X R D)$ e espectroscopia de infravermelho com transformada de Fourier (FTIR). As análises forneceram novas informações sobre os materiais e técnicas de decoração que variaram ao longo do bastão. Este estudo é o primeiro passo na determinação dos materiais e técnicas de decoração usados para produzir este particular tipo de bastão durante o período do rei Tutankhamon.

\section{Keywords}

Tutankhamun

Decorated wooden stick

Gilded bark

Wood identification

X-ray fluorescence

Fourier transform infrared spectroscopy

\section{Palavras-chave}

Tutankhamon

Bastão de madeira decorado

Casca dourada

Identificação de madeira

Fluorescência de raios $X$

Espectroscopia de infravermelho com

transformada de Fourier

ISSN 2182-9942 


\section{Introduction}

The tomb of Tutankhamun (KV62), which was discovered intact in 1922 by Howard Carter, was embellished with an incredible set of finely crafted furniture [1]. More than 130 complete or fragmented specimens of sticks were found in the antechamber, in the burial chamber and in the annex of the king's tomb. Many of these sticks served obviously for ritual purposes, others, however, showed signs of different use. There were different types: long sticks with knobbed and forked tops and ferruled bottoms, and crooked and curved sticks used to kill snakes. Some of them were mounted with gold and silver and others were decorated with marquetry of barks, or with polished and flat wood [2-3]. The diversity of materials and techniques used in these sticks shows highly professional skills and a sophisticated sense of beauty, however these sticks have never been scientifically investigated since the discovery of the tomb. For proper conservation procedures, it is important to understand how these techniques were performed and how composite materials were prepared to decorate them, as well as to allow the understanding of the entire method, meaning how different layers were adhered to each other.

In this work we demonstrate the ability of combined scientific and analytical measurements, including optical microscopy (OM), environmental scanning electron microscopy (ESEM), X-ray fluorescence (XRF), $\mathrm{X}$-ray diffraction (XRD) and Fourier transform infrared spectroscopy (FTIR), to answer some questions related to this topic: What type of wood and bark were used? Was pure gold or gold alloy employed for gilding? Was the same type of gold leaf used in the different parts of the object? How were the gilded layers applied? What type of varnish and black resinous layers was used? What is the chemical composition of the white ground (gesso) layer? Moreover,
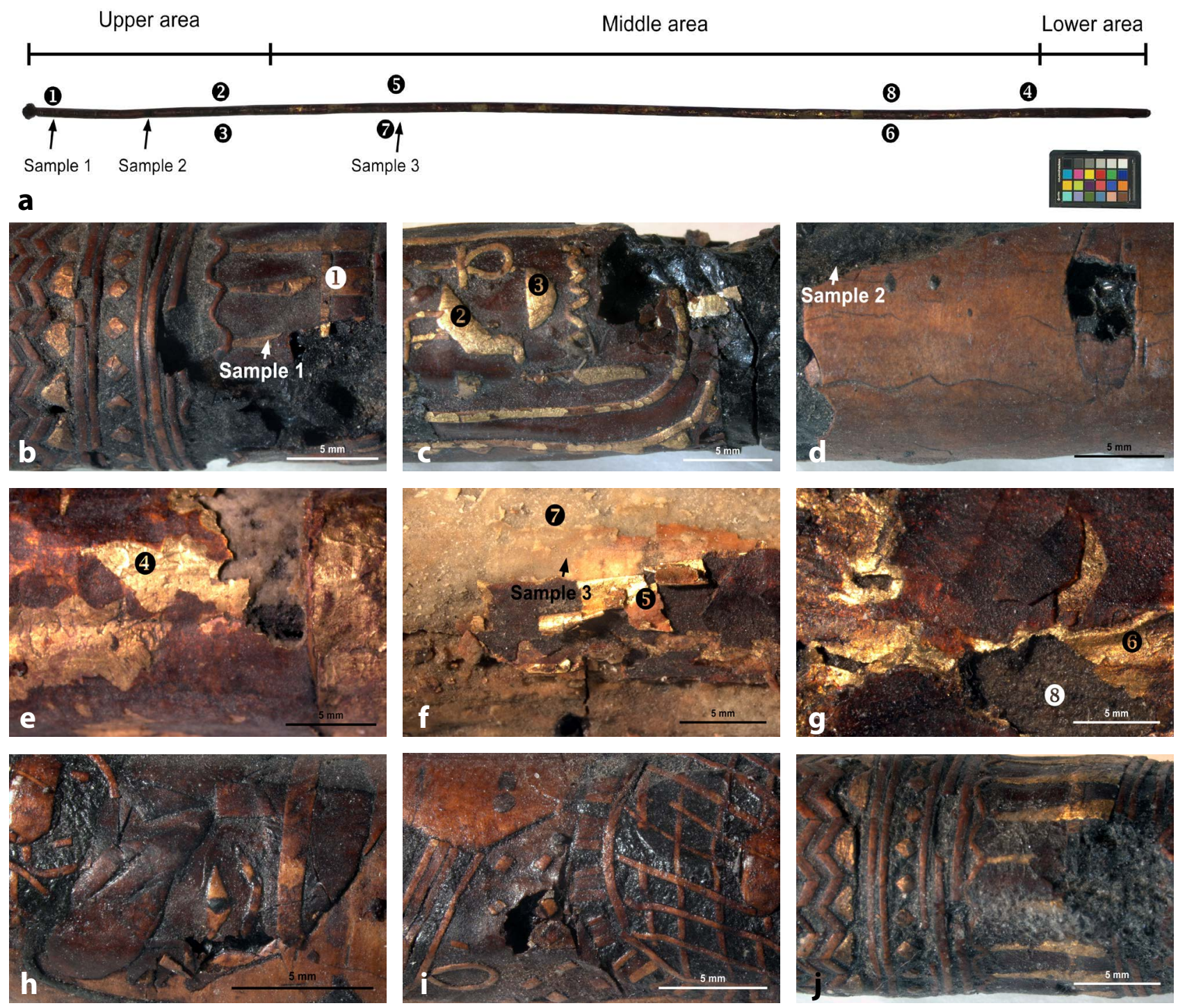

Figure 1. The stick and detailed images for different areas of the decorated layers showing spots, locations and the deterioration aspects under stereo microscope: a) general image for the stick showing locations from which the spots and samples were taken for analysis (XRF spots indicated by circles, samples by arrows); $b-d$ ) deterioration aspects of the upper area of the stick; $e$-g) deterioration aspects of the middle area; $h$-j) deterioration aspects of the lower area. 
the authors were significantly interested in unfolding the cylindrical decorations by using a combination of IR imaging and an axial rotating device along with adobe Photoshop and 2D software.

\section{Historical background of the stick}

The studied stick (Figure 1a) is at about $152 \mathrm{~cm}$ in length and $2.1 \mathrm{~cm}$ in maximum diameter, and it was found among a group of sticks stacked carelessly against a wall on the left side of the entrance of the king's tomb, inside the antechamber, registered under Carter number 135e. According to Carter's handwritten notes, the object was previously consolidated by paraffin wax [4], prior to be transferred to the Egyptian Museum in Cairo, where it was kept in the storage 55 under the number JE 60696. After long-term storage, the stick was transported to the Wood Conservation Laboratory of the Grand Egyptian MuseumConservation Center (GEM-CC) in 2012, where this study was conducted. As shown in Figure 1a, the stick is made of wood and is coated with colored and gilded bark decorations, consisting of geometrical patterns and cartouches containing the names of the king Tutankhamun in the upper area and representation of captive figures and geometrical patterns in the lower area. The middle area is covered by varnished gilded white ground layer without any decoration.

\section{Materials and methods}

\section{Sampling}

The spots analyzed by XRF and all the sampling areas are shown in Figure 1a, and details are shown in Figure 1b-g. XRF analyses were performed directly on different areas of the object. As the decorated layers of the object are detaching and flaking, three fallen samples $(1,2,3)$ representing the different layers were carefully chosen for the analyses. From the fallen samples, cross-sections were prepared using epoxy resin (Epofix, Struers). Also, a sample from the previous consolidating material was carefully scraped off with a metallic scalpel for the analysis.

\section{Identification of wood and bark}

In order to identify the botanical species, thin sections of wood and bark samples were examined under transmitted light using Opitka Microscopy (Italy) equipped with Optika B9 Digital Camera. The observation and description of anatomical features allowed the identification of the taxon of the wood and bark samples through comparison with the description available in wood anatomy textbooks, atlases and database [5-8].

\section{Optical microscopy (OM)}

The investigation of the texture of the decorated surface using OM allowed a detailed evaluation of the stick's condition. Moreover, this technique is essential to provide a documentation of the areas examined by spectroscopic techniques. OM images were acquired using a portable microscope a Zeiss Stereo DV 20 equipped with an Axio Cam MRC5.

\section{Environmental scanning electron microscopy (ESEM)}

Stratigraphic investigations were performed by environmental scanning electron microscopy. ESEM images, by backscattered electrons (BSE), were taken with a Quanta 3D 200i scanning electron microscope produced by FEI.

\section{X-ray fluorescence spectroscopy (XRF)}

The measurements were conducted with a Niton XL3t GOLDD hand held XRF spectrophotometer using the NITON XL3t X-ray tube based analyzer with Ag anode, 50 $\mathrm{kV}$ and 0-200 $\mu \mathrm{A}$ max. The instrument head was placed in contact with the selected areas, irradiating an area of at about $3 \mathrm{~mm}$ radius. All points were exposed for tens of seconds. XRF spectra were produced using Niton Data Transfer (NDT) software.

\section{Fourier transformed infrared spectroscopy (FTIR)}

Fourier transform infrared spectroscopy measurements were performed using FTIR spectrometer (Vertex 70, Bruker) equipped with an attenuated total reflection (ATR) accessory, in the 400-4000 $\mathrm{cm}^{-1}$ range, with spectral resolution of $8 \mathrm{~cm}^{-1}$. The organic materials were identified by comparison of the obtained spectra with data from literature [9], and reference spectra obtained in the laboratory.

\section{X-ray diffraction (XRD)}

The gesso layer was analyzed in a nondestructive way without any sample preparation by X-ray diffraction, using an X-ray diffractometer system (PW3040 Analytical Equipment - PANalytical pro model) with a $\mathrm{Cu}$ anode, working at $30 \mathrm{~mA}$ and $40 \mathrm{kV}$ (an approximately flat surfaced sample was attached into the sample holder inside the XRD apparatus). X'Pert High score data acquisition and interpretation software was used to determine the components of the gesso layer.

\section{Documentation of the stick condition}

The IR photographic documentation was made with a Nikon D90 DSLR digital camera modified for full spectrum fitted with a Nikon Nikkor $105 \mathrm{~mm}$ lens. The excitation was provided by two LED IR radiation sources ( 900 $\mathrm{nm}$ ) and the camera lens was fitted with a Fuji 850 cut-on filter. The camera was positioned on a tripod and the object was put on an axial rotating device; this is an innova- 
tive technique designed specifically for photographing the cylindrical sticks. It facilitates the rotation of the sticks, provides eight images for each $45^{\circ}$ rotation and facilitates the unfolding of the images by Adobe Photoshop [10]. In our case study, the object has been rotated in steps of $45^{\circ}$ till reaching the full rotation providing 8 images, which were then photomerged by adobe Photoshop software. The final unfolding picture was then elaborated by a computer aided drawing program (2D).

\section{Results and discussion}

\section{The stick condition}

In our close observation under stereomicroscope, the stick showed to be produced by complex layers and intricate methods that caused detachments, cracking, and missing of parts (Figures 1b-1d). Friable gesso layer was noted and the gilded layers were confirmed to be in an unstable condition, and many of them are poorly attached. Their edges were curled away from the gesso surface, which indicated to be brittle by touching (Figures 1e-1f). Cracks and brittleness were observed on the varnish layer, which lost its transparency obscuring the gilded layer beneath on it (Figure $1 \mathrm{~g}$ ). Figures $1 \mathrm{~h}-1 \mathrm{j}$ show the negative impacts of the previous consolidating material, which attracted dust and obscured details of some decorated surfaces. In this study, no hidden details were revealed by infrared technique, as shown in Figure 2 , but the contrast between the black layer and the bark was enhanced, making the decorations more evident (which did not clearly appear in the visible light due to the negative impacts of the previous treatments). This is because the black layer absorbs infrared radiation nearly as strongly as it absorbs visible light, while the bark (even in the areas where it is stained and discolored) absorbs infrared radiation less strongly than in the visible region.

\section{Identification of wood}

The microphotographs of wood thin sections showed that the wood type is almond tree (Prunus dulcis). The anatomical characteristics of the transversal section shows growth ring boundaries distinct by the difference in vessel size between latewood and early wood, semi-ring porous to ring-porous wood, vessels solitary and in radial multiples of 4 or more, as well as axial parenchyma diffuse and scanty paratracheal (Figure 3a). Simple perforation plates, body ray cells procumbent with mostly 2-4 rows of square marginal cells and crystal druses in ray parenchyma cells were observed as seen in the radial longitudinal section (RLS) (Figure 3b). Two distinct sizes of rays: uniseriate and 2 to 4 seriate were observed in the tangential longitudinal section (TLS) (Figure 3c), as well as inter-vessel pits alternated and helical thickenings presented on vessel walls (Figure 3d). This kind of wood was recorded to be imported and used for making walking sticks in the ancient Egypt [11-13]. It is characterized by a high percentage of fibers and narrow wood vessels [14], which give these woods properties of hardness, strength, density and durability, as well as long frequent dimensions of branches found on these trees [13], which made Prunus dulcis a considerably suitable wood for manufacturing the sticks.

\section{Identification of bark}

Bark was used from as early as the Neolithic period; however, it is clear that objects covered with bark as a
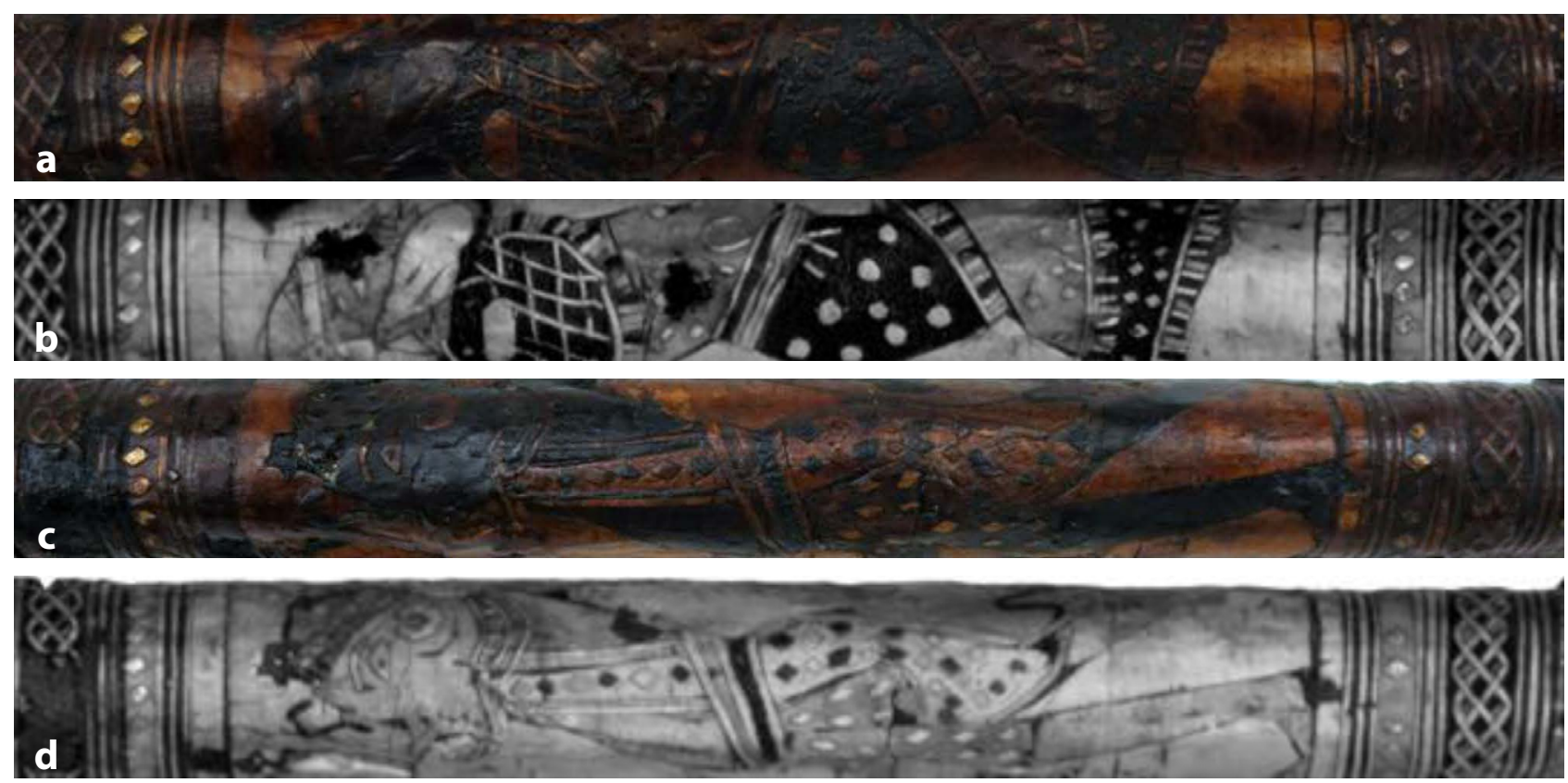

Figure 2. Technical images for the lower area of the stick (the enemy's figures) made by visible (VIS) imaging (a, $c$ ) and infrared (IR) imaging $(b, d)$. 

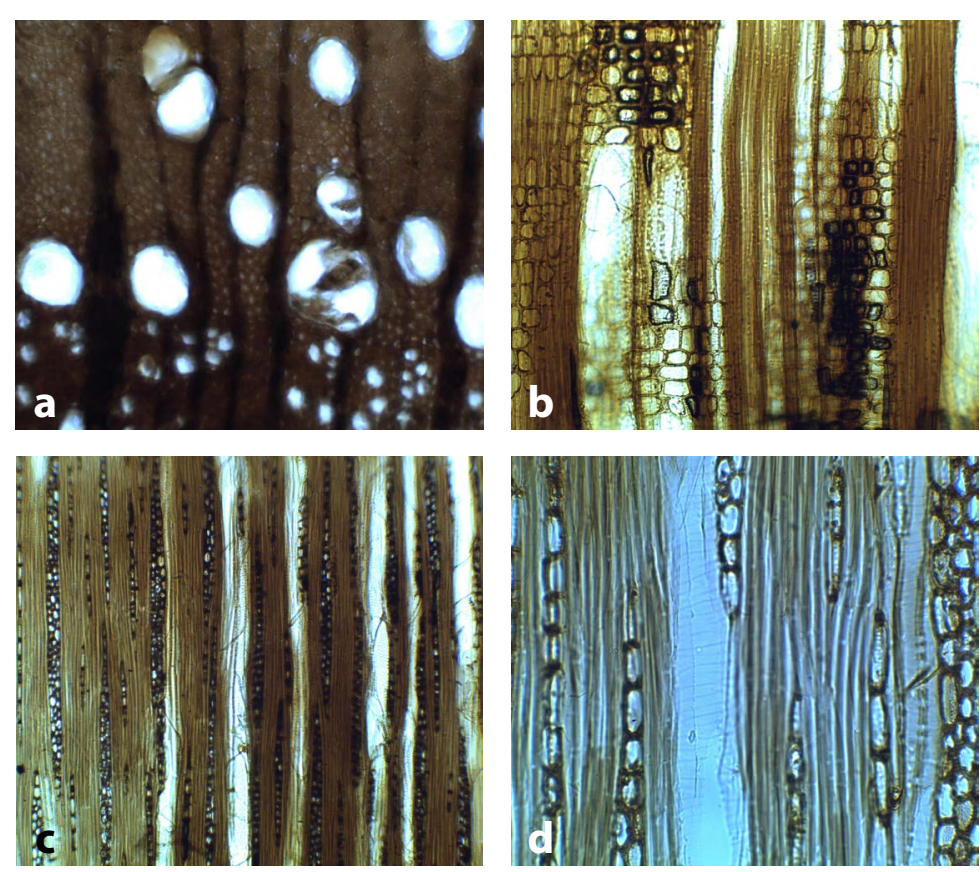

Figure 3. Microphotographs of wood thin sections under optical microscope in transmitted light showing the anatomical characteristics of Prunus dulcis: a) transverse section (TS); b) radial longitudinal section (RLS); c) tangential longitudinal section (TLS); d) detail of tangential longitudinal section (TLS). Magnifications: $a, b$ 200×; $c$ 100×; $d$ 400×.

decorative finish to timber held special significance to ancient Egyptians in later periods, in particularly during the Eighteenth Dynasty [12]. No previous identification was performed on the ancient Egyptian objects. However, Lucas and Harris suggested that a number of objects in the tomb of Tutankhamun such as bows, a bow box, sticks, a fan handle and a chariot axle were covered with bark probably obtained from birch (Betula sp), which was mentioned to be imported from Armenia [15]. Same authors stated that cherry bark might sometimes be used. In our case study, the microscopic observation of the bark radial cross section showed that the bark was probably obtained from birch tree of the genus Betula. In Figure 4a the radial cross section showed presence of numerous cork layers, which consisted of two distinctive cell types in alternate rows. The first type of cells has a very broad radial dimension with thin cell walls, while the second type has a very narrow radial dimension with thick cell walls (Figure 4b). These barks of the genus Betula are characterized by high amounts of a waxy hydrophobic substance called suberin, which give them barks properties of density and protection from pathogens such as fungi, insects and bacteria [16]. In addition, birch bark can be removed in large sheets and withstand changes in shape without breaking $[12,17]$. Such unique properties made birch bark a suitable choice for decorating sticks.

\section{Identification of the stratigraphic structure}

The observation of the stick revealed the presence of different decoration layers on the wood surface, varying from top to bottom. Studying the cross-section of sample 1, it was observed that it consists of three different layers of different thickness, Figure 5a. The first (lower) layer is a black resin layer, with an average of $400 \mu \mathrm{m}$ thickness. The second layer contains bark layer, with an average of $120 \mu \mathrm{m}$ thickness. The third is a gold leaf of 10 to $16 \mu \mathrm{m}$ thickness. In ancient Egypt, it was not a common practice to use gold leaf on birch bark for the decoration of furniture and this technique has never been reported in the conservation literature.

Studying the cross-section of sample 2, it was observed that it consists of two different layers, Figure 5b. The first (lower) layer is a black resin layer. The second layer contains bark layer, with an average of $160 \mu \mathrm{m}$ thickness. From backscattered electron micrograph for sample 3 (Figure 5c), the occurrence of four different layers was observed. The first (lower) layer is a single white ground layer, of many micrometers thickness. The second intermediate layer is a gold leaf of 8.8 to $9.8 \mu \mathrm{m}$ thickness. The third is a varnished layer, with an average of $30 \mu \mathrm{m}$ thickness. In addition, dirt adhered to the varnish layer was also observed as a fourth layer. It was a common practice to use gold leaf on a white ground layer for the decoration of furniture in ancient Egypt, in particular in the New Kingdom, and this technique was reported by some authors $[15,18-20]$.

\section{Identification of gold leaf composition}

Most of the gold used in ancient Egypt was obtained from alluvial deposits and from quartz rock which lay between the Nile and the Red Sea [21]. They ranged from those of very high purity to those containing at least 40 $\%$ of silver (electrum) and copper with percentages not higher than $1.5 \%$ [22]. Some of the ancient Egyptian
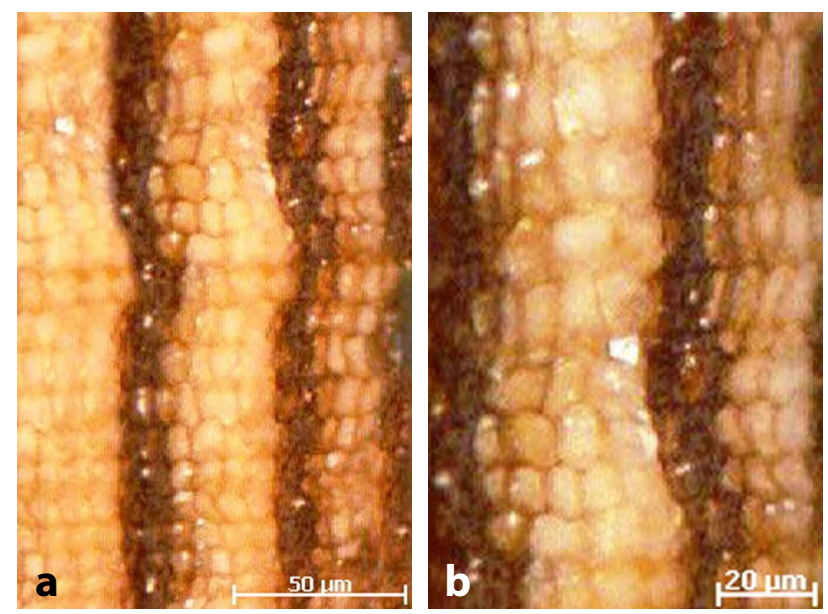

Figure 4. Microphotographs of bark sample under optical microscope: a) radial cross-section; $b$ ) details of radial crosssection. 

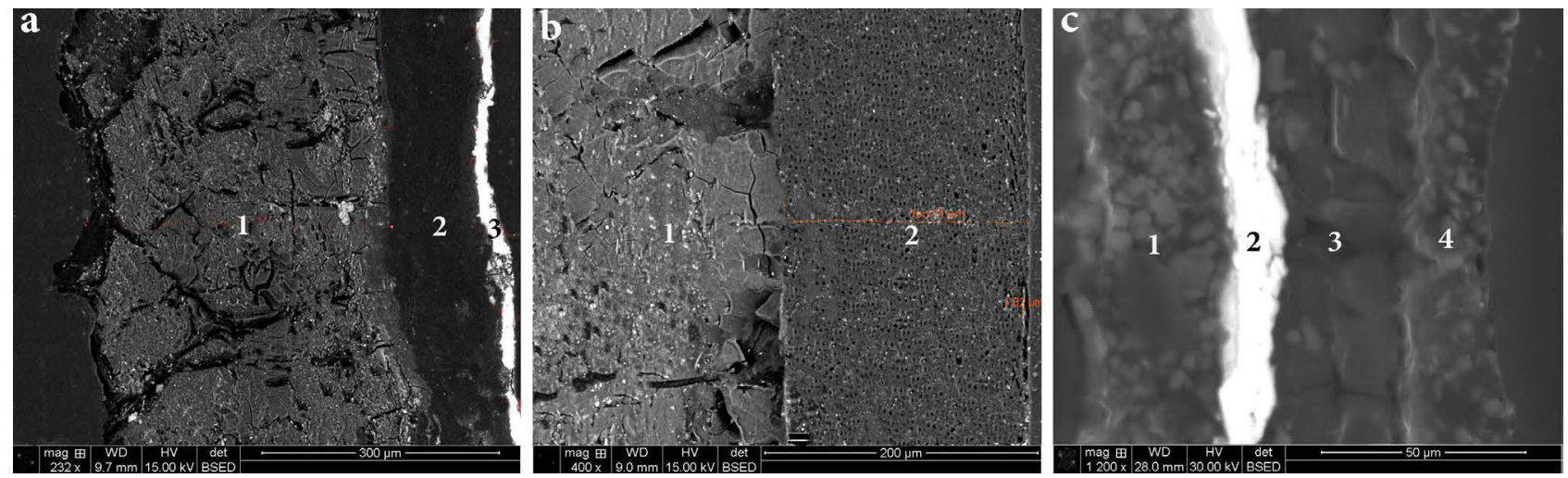

Figure 5. BSE micrographs of the fallen decorated samples from different areas showing the stratigraphic structure of the decorated layers: $a$ ) sample $1 ; b$ ) sample $2 ; c$ ) sample 3.

objects are made of solid gold, but the majority of golden objects are only gilded, either with gold foil or with gold leaf. There is no evidence to suggest that the Egyptians made a terminological distinction between gold leaf and gold foil [21], however we used the terminology of gold leaf to describe the gilding techniques discussed in this paper according to previous works $[15,18]$, that defined gold leaf as a sheet having a thickness of 1-90 $\mu \mathrm{m}$. Generally, gilding is the technique of applying a thin sheet of gold over a solid support to achieve the rich appearance of solid gold. Gold leaf was produced by hammering a thin sheet of pure gold or gold alloy with small amounts of silver, copper or other metals [18]. Moreover, Hatchfield and Newman concluded that the production of extremely thin gold leaf on ancient Egyptian artifacts from diverse periods was not dependent on the availability of extremely pure gold, whether from native or refined sources [19].

Table 1 summarizes the composition of the gold leaf from different areas of the stick as shown in Figure 1. The data indicated that gold leaf adhered to bark (spots no. 1, 2 and 3) is very pure, composed of gold (Au) with percentages of 96.7 to $97 \%$ (approximately 23.5 karat) followed by small amounts of lead $(\mathrm{Pb}, 0.7 \%)$, iron $(\mathrm{Fe}$, $0.8 \%$ ) and copper $(\mathrm{Cu})$, with percentage of about $0.4 \%$. Almost no silver (Ag) was observed. This composition

\section{Table 1}

XRF results from different areas of gold leaf

\begin{tabular}{|c|c|c|c|c|c|c|c|c|}
\hline \multirow{2}{*}{$\begin{array}{l}\text { Spot } \\
\text { no. }\end{array}$} & \multicolumn{8}{|c|}{ Element concentration (\%) } \\
\hline & $\mathrm{Au}$ & $\mathrm{Ag}$ & $\mathrm{Cu}$ & $\mathrm{Fe}$ & $\mathrm{Pb}$ & $\mathrm{Zn}$ & $\mathrm{Cr}$ & $\mathrm{Ti}$ \\
\hline 1 & 96.7 & - & 0.33 & 0.68 & 0.84 & 0.23 & 0.62 & 0.41 \\
\hline 2 & 96.6 & - & 0.34 & 0.73 & 0.83 & 0.24 & 0.67 & 0.37 \\
\hline 3 & 97.1 & - & 0.23 & 0.72 & 0.65 & 0.21 & 0.65 & 0.35 \\
\hline 4 & 93.7 & 3.6 & 0.64 & 0.52 & 0.43 & 0.18 & 0.58 & 0.14 \\
\hline 5 & 93.1 & 4.1 & 0.68 & 0.49 & 0.51 & 0.19 & 0.82 & 0.17 \\
\hline 6 & 93.5 & 3.4 & 0.74 & 0.45 & 0.57 & 0.21 & 0.40 & 0.20 \\
\hline
\end{tabular}

with a higher level of gold purity is in agreement with the composition of other ancient Egyptian gold leaf previously determined [18-19, 23]. Despite this, the gold leaf adhered to the ground layer (spots no. 4, 5 and 6) showed the presence of Ag. In all the spots $\mathrm{Au}$ had the highest concentration with percentages between 93 to 93.5\% (approximately 22.5 karat); is followed by Ag, which composition was at about 3.5 to $4 \%$, and the percentage of $\mathrm{Cu}$ was the lowest of all the elements present in it, with about $0.7 \%$. Small amounts of $\mathrm{Pb}(0.5 \%)$ and $\mathrm{Fe}(0.6 \%)$ were also observed. This composition with Ag content that can reach $4 \%$ is also in agreement with the set of gold leaf dated to different periods characterized by Hatchfield and Newman [19], and with the composition of the gold leaf of sample 2 from the tomb of Tutankhamun published by Rifai and El Hadidi [18].

\section{Identification of previous consolidating material}

The FTIR analysis of previous consolidating material (Figure 6) showed the presence of characteristic peaks of C-H stretching mode at $2916 \mathrm{~cm}^{-1}$, C-H bending mode at $1463 \mathrm{~cm}^{-1}$ and $\mathrm{C}-\mathrm{H}$ torsion mode at $728 \mathrm{~cm}^{-1}$, which ascribed to paraffin wax $[9,24]$, a macro crystalline wax produced by distillation of petroleum and used frequently in the surface treatment for damaged objects of Tutankhamun's collection during the discovery of the tomb [25]. This result is in agreement with the Carter's handwritten of the object [4].

\section{Identification of white ground (gesso) layer}

It was a common practice in ancient Egypt to use a white ground (gesso) layer adhered to either wood surface or an intermediate textile layer surface, to produce a smooth surface to paint or gild wooden objects and funerary furniture [15]. In Figure 7 the XRF spectrum of gesso layer (spots no. 7 and 8) is shown. This spectrum shows the presence of calcium $(\mathrm{Ca})$ as the main element with small amount of silicon ( $\mathrm{Si}$ ) and traces of $\mathrm{Fe}$ and titanium (Ti) as inclusions. The absence of sulphur in this spectrum sug- 


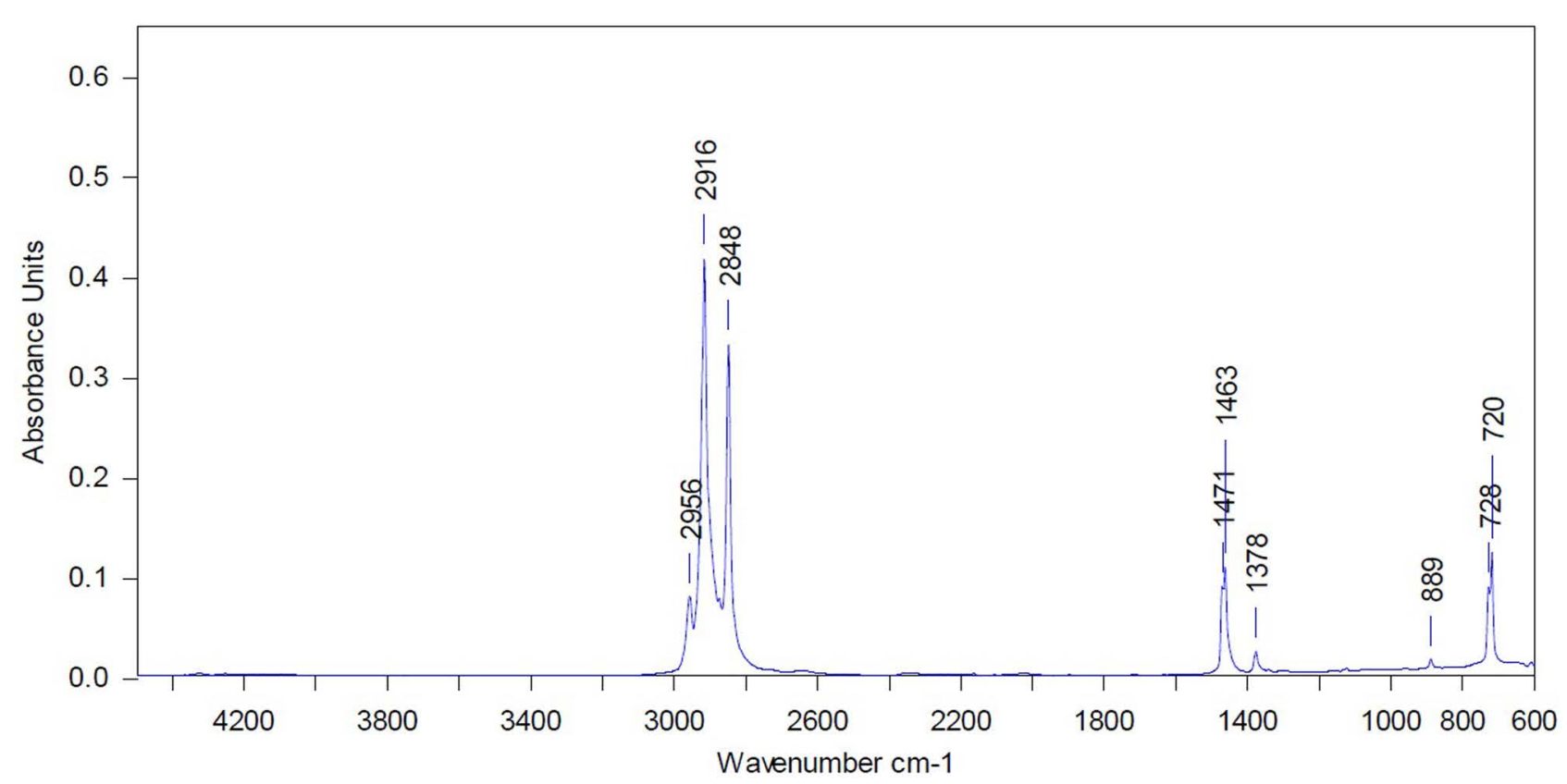

Figure 6. FTIR spectrum of previous consolidating material.

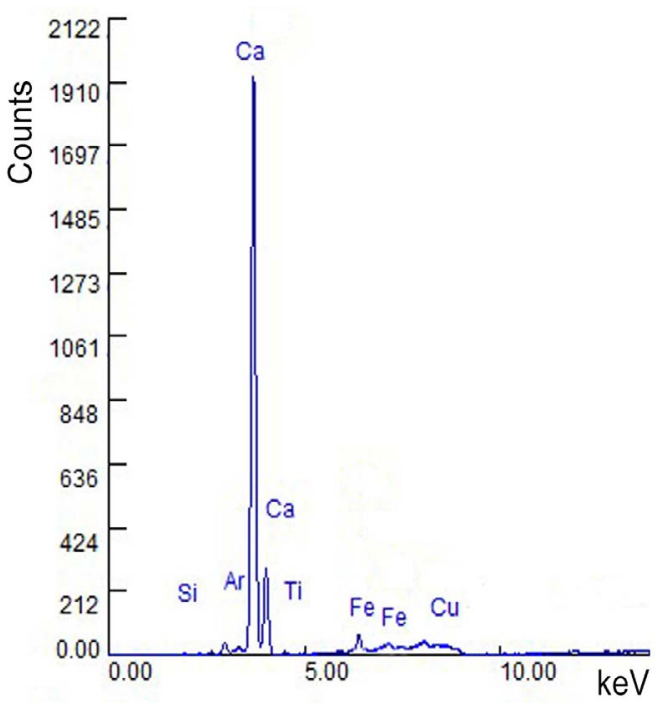

Figure 7. XRF spectrum of white ground (gesso) layer.

gests that this layer is composed of a calcium carbonate $\left(\mathrm{CaCO}_{3}\right)$ and quartz $\left(\mathrm{SiO}_{2}\right)$. In Figure 8 the infrared spectrum of gesso layer from sample 1 is shown. In this spectrum we can identify calcium carbonate and quartz; this was evidenced from the stretching vibrations of $\mathrm{CO}_{3}{ }^{2-}$ group at 1396, the bending vibrations of $\mathrm{C}-\mathrm{O}-\mathrm{C}$ group at 870 and $711 \mathrm{~cm}^{-1}[9,26-27]$, and the stretching vibrations of $\mathrm{Si}-\mathrm{O}-$ Si group at 1099, 1043 and $779 \mathrm{~cm}^{-1}$ [26-28]. This spectrum also shows the presence of a band at $1619 \mathrm{~cm}^{-1}$, assigned to $\mathrm{C}=\mathrm{O}$ stretching of amide $\mathrm{I}$ and a band at $1557 \mathrm{~cm}^{-1}$, assigned to $\mathrm{N}-\mathrm{H}$ bending of amide II, which was confirmed by the $\mathrm{N}-\mathrm{H}$ stretching band at $3328 \mathrm{~cm}^{-1}$. These are characteristics of proteinaceous based material such as animal glue $[9,29]$, which was commonly used as binding medium in gesso layer from very early period in ancient Egypt [30].
XRD result (Figure 9) shows the presence of calcite and some quartz, in agreement with the gesso layer composition indicated from XRF and FTIR results. This composition agrees with the composition of gesso layers previously determined by Rifai and El Hadidi [18].

\section{Identification of varnish layer}

In the New Kingdom, many of the Egyptian funerary objects were coated with varnish, originally clear, but darkened over time to yellowish when thinly applied and to a reddish-orange when thickly applied [15, 30]. More analysis showed that the main component in the yellow varnish was pistacia resins such as mastic, a triterpenic resin that comes from a small tree that grows on Mediterranean coasts [31-33]. The FTIR spectrum of the varnish layer with its superficial dirty layer in sample 1 (Figure 10) is very complex. Nevertheless, most of the observed bands are probably related to the superficial dirty layer. Indeed, bands at 1621,1315 and $779 \mathrm{~cm}^{-1}$ are strongly suggestive of calcium oxalate [35-36], besides those that can be assigned to proteinaceous based material at 1621, 1540 and $1409 \mathrm{~cm}^{-1}$; and bands assigned specifically to paraffin wax, at 2918, 2849, 1461 and $729 \mathrm{~cm}^{-1}$. Finally, the spectrum of Figure 5 also shows some week absorptions at 1461,1171 and $1099 \mathrm{~cm}^{-1}$, probably related to pistacia resin [9, 34]; however further analysis using micro-FTIR spectroscopy and GC-MS will be necessary to determine the identity of the varnish layer itself more precisely.

\section{Identification of black resinous layer}

The black resinous layer was applied in several objects in the New Kingdom probably to enhance the appearance of these funerary objects as well as its religious 


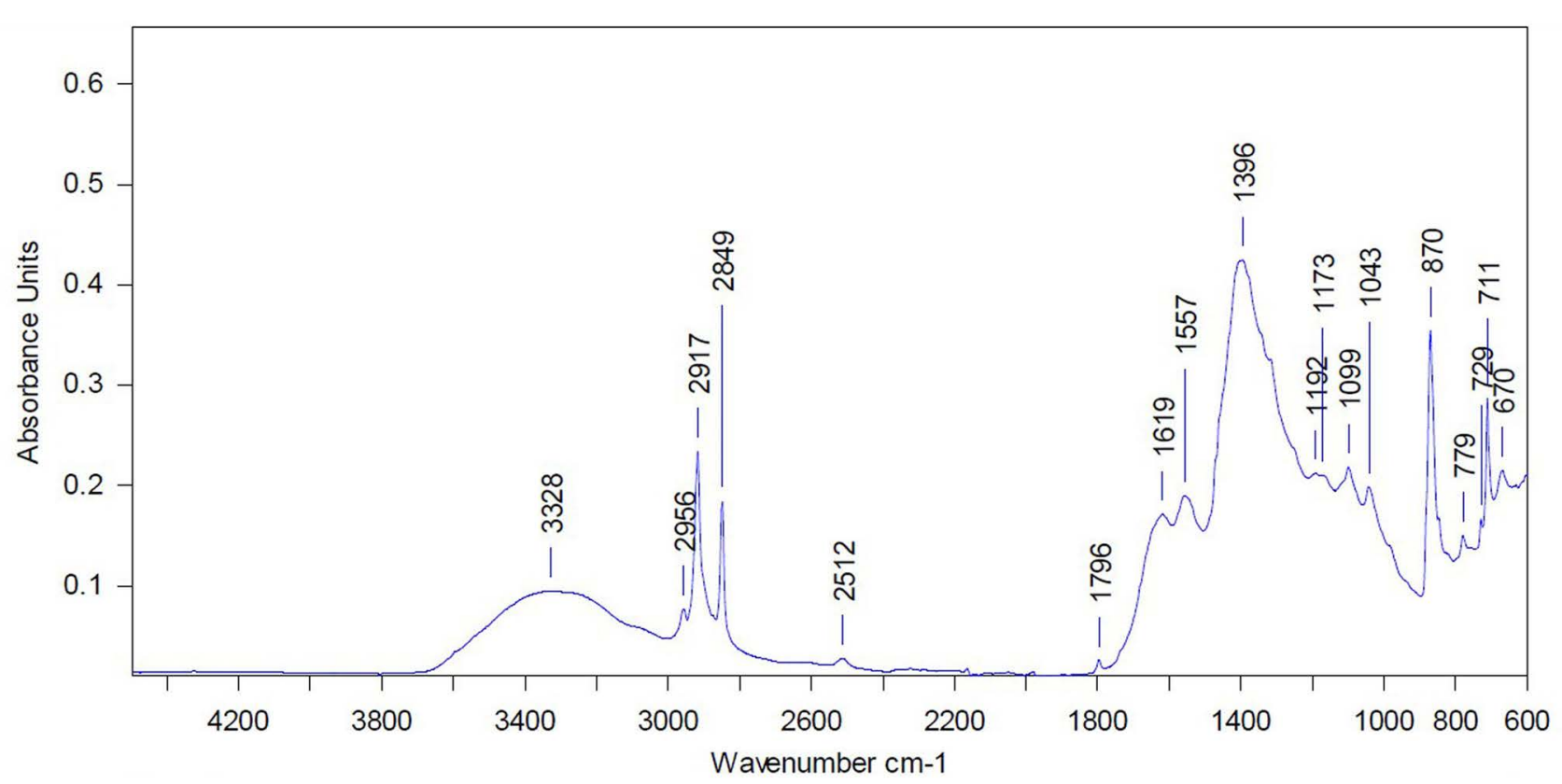

Figure 8. FTIR spectrum of white ground (gesso) layer.

importance, which was probably the primary reason for their usage [31]. The recent analysis showed that the black resinous layers or coatings consist of complex composition with diverse materials including oils, resins, fats, bitumen and wax [30, 31, 36]. In addition, this layer is often not completely black, but has a brownish color [32]. In our case study, the black resinous layer was used as a base to hold the bark decorations, which is an unusual practice in ancient Egypt. FTIR spectrum of the black resinous layer in samples 2 and 3 (Figure 11) is more complex. It shows characteristic peaks of C-C stretching mode at $1644 \mathrm{~cm}^{-1}$, $\mathrm{C}-\mathrm{H}$ bending mode at $1389 \mathrm{~cm}^{-1}$ and $\mathrm{C}-\mathrm{O}$ stretching mode at $1171 \mathrm{~cm}^{-1}$ and other peaks at 2917 and $3200 \mathrm{~cm}^{-1}$, that may be assigned to the presence of Pistacia resins, such as mastic $[9,34]$. The spectrum from Figure $7 \mathrm{~b}$ also shows weak absorption peaks at 1315 and $779 \mathrm{~cm}^{-1}$, probably assigned to calcium oxalate, which was also determined in previous works [11]. This layer is especially unusual and it would be worthy of more detailed examination;

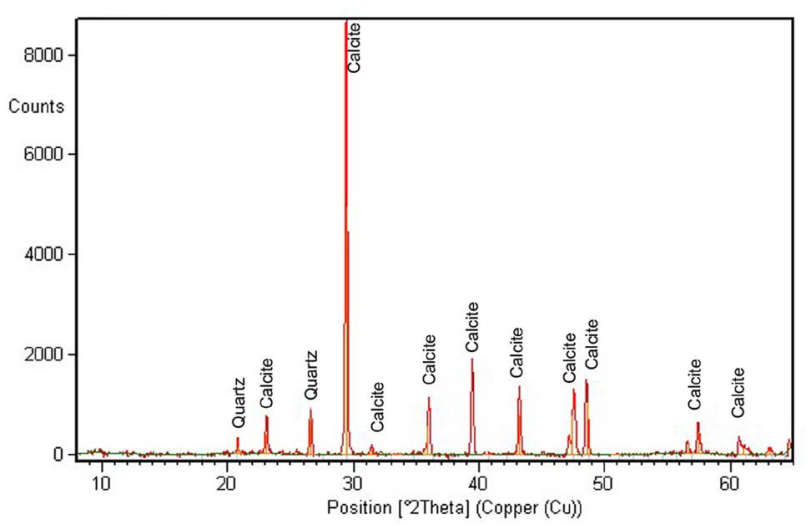

Figure 9. XRD pattern of white ground (gesso) layer. therefore further analysis using gas chromatography-mass spectrometry (GC-MS) will be necessary to determine its identity more precisely.

\section{Documentation of the stick condition}

At last, in Figure 12, it is shown an example of the documentation of the lower area of the stick after using a combination of IR imaging and an axial rotation device along with adobe Photoshop and 2D software. It illustrates 2D schematic diagram for the lower area after unfolding the cylindrical decorations, which allowed us to obtain a complete representation of two captive figures together and geometric patterns, as well as all deterioration aspects were recorded. Key note anchored to the 2D schematic diagram gave information on every type of deterioration aspects where every deterioration aspect has a distinguish hatch (its color varied according to the layers of the stratigraphic structure of the object, e.g. green color has been used to express the bark; combining the green color with hatch type means that the deterioration aspects exist only in the layer of bark).

The advantage of this kind of documentation is the provision of a complete unfolded picture for the cylindrical decorations of every part of the object and a record of all the surface texture decorations and alterations of the object in a single map linked to the object without the necessity of having several maps for the different sides of the same part.

\section{Conclusion}

The paper presents the investigation of a decorated wooden stick from Pharaoh Tutankhamun funerary collection. A combination of some analytical techniques 
(OM, ESEM, XRF, XRD and FTIR) was employed to determine the materials used to produce the stick, while the coupling of IR imaging and an axial rotation device along with adobe Photoshop and 2D software was applied with the aim of unfolding the cylindrical decorations and recording all alterations of the stick. The microscopic observation of wood thin sections allowed identifying it as almond tree (Prunus dulcis), while bark was obtained from birch bark (Betula sp). These choices indicated that the ancient Egyptian carpenters were aware of characteristics of tree wood and barks. The gesso layer was proved to be calcium carbonate and small amount of quartz bound with an organic binder, which was probably composed of a protein-based material such as animal glue. The main component of the black resinous layer was probably composed of pistacia resin. Paraffin wax was identified as the consolidating material applied in the previous intervention treatment. XRF results of gold leaf adhered to bark showed a higher level of gold purity than those have been found in gold leaf adhered to the gesso layer. This variation is not unexpected and it is also in agreement with the composition of other ancient Egyptian gold leaf previously determined. Applying gold leaf on a birch bark has never been reported and it is considered to be a unique technique at that time. The use of the black resinous layer to hold the birch bark indicated

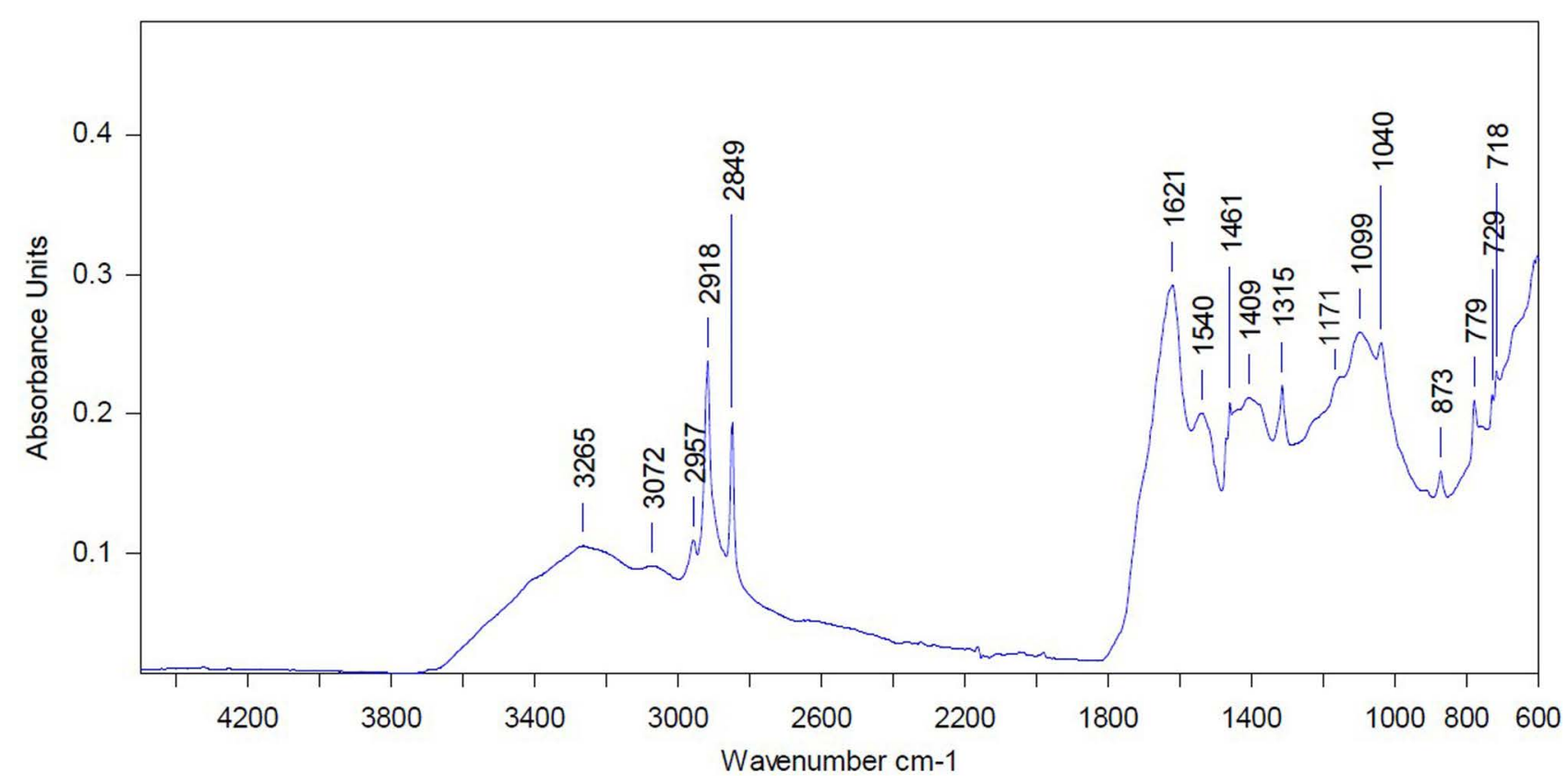

Figure 10. FTIR spectrum of the outer layer of varnish.

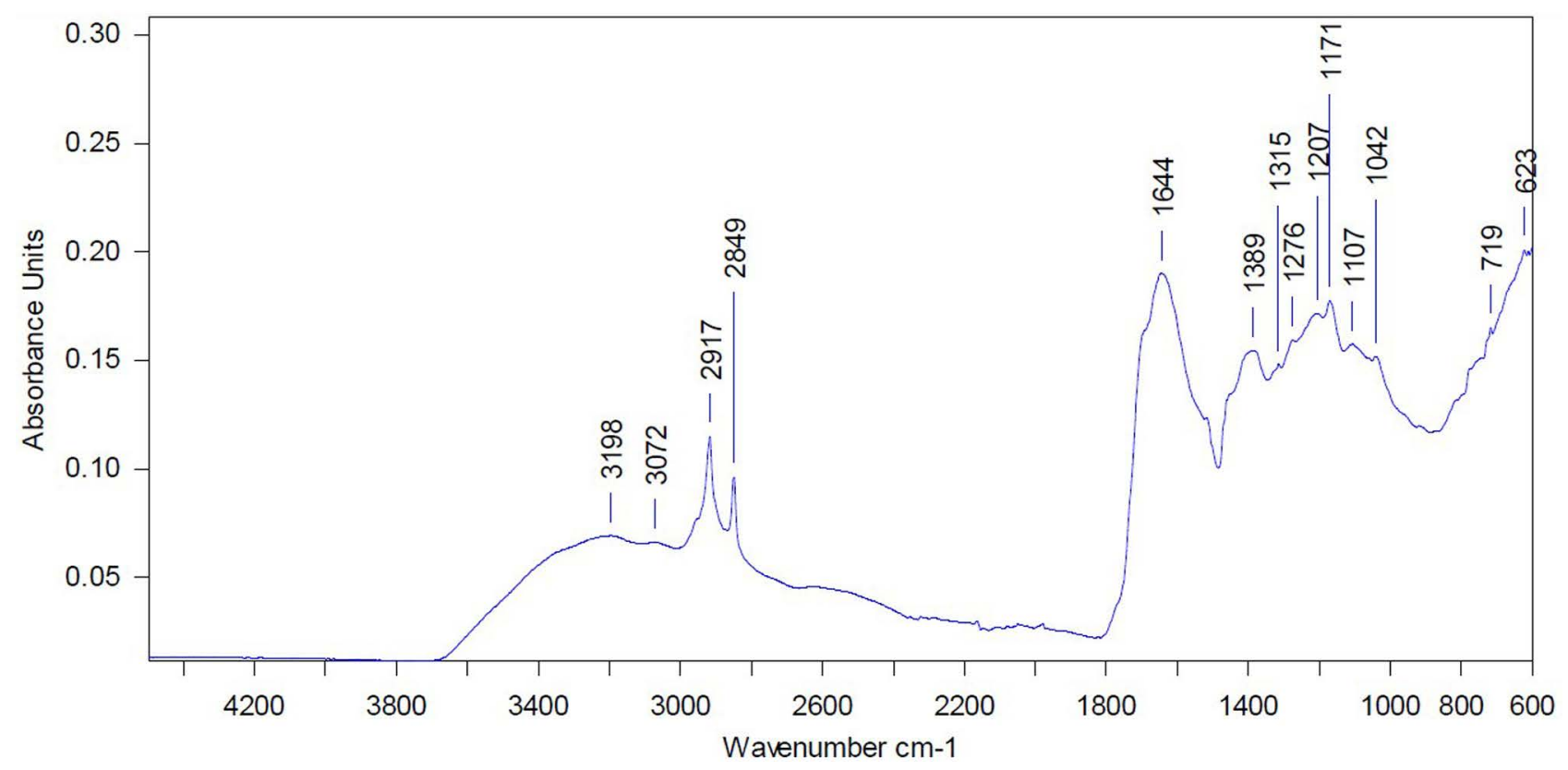

Figure 11. FTIR spectrum of black resin layer. 

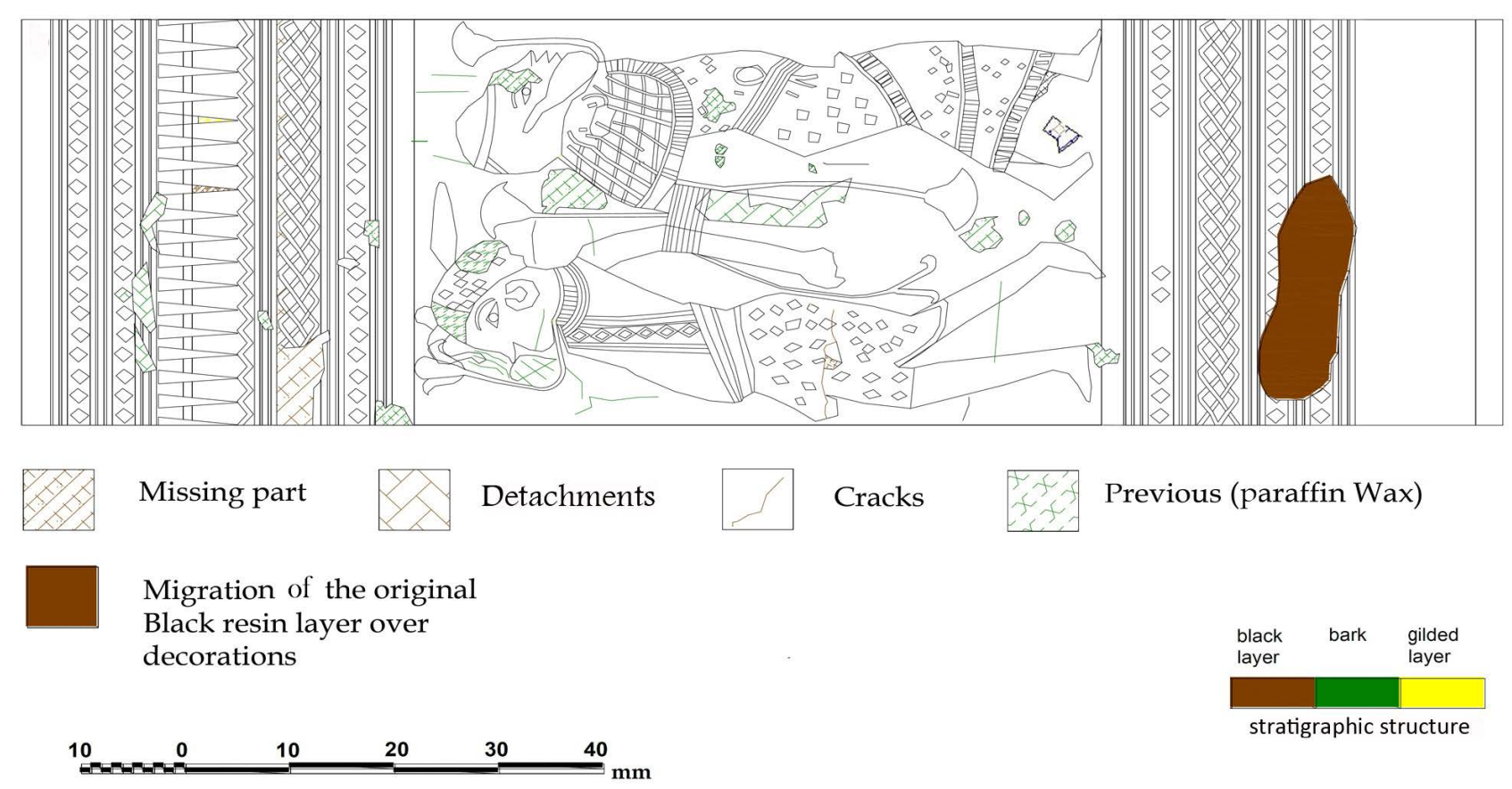

Figure 12. The $2 \mathrm{D}$ schematic diagram of the lower area of the stick after unfolding.

that the ancient Egyptian were aware of characteristics of the materials. The coupling of IR imaging and an axial rotation device along with adobe Photoshop and 2D software provided a useful technique for unfolding the surface texture cylindrical decorations and recording all alterations of the stick in a single map linked to the object. The results of this research represent a first step in determining the materials used to produce this particular kind of sticks during king Tutankhamun period, however complete characterization of some materials requires the use of other techniques, such as GC-MS and micro-FTIR spectroscopy.

\section{Acknowledgments}

The authors would like to thank staff-members of GEMCC; Wood Lab, SEM Lab, FTIR Lab and XRD Lab for assistance. The authors are also much grateful to Mr. Hassan Mohamed El Sayed, Supervisor of the special case artifacts unit, Dr. Ossama Abo El khair, the General Director of Conservation affairs and Dr. Tarek Tawfik, General Director at GEM.

\section{ORCID}

Ahmed Abdrabou

(iD) https://orcid.org/0000-0003-3423-3884

\section{References}

1 Hepper, N., Pharaoh Flowers Botanical Treasure of Tutankhamun, KWS Publishers , London (1990).

2 Reeves, N., The Complete Ankh Amen (the King - the Tomb the Treasury), The American University in Cairo Press, Cairo (1990).

3 Carter, H., The Tomb of Tutankhamen, vol. 3, London (1963).
4 'Carter no. 135e', in Tutankhamun: Anatomy of an Excavation, The Griffith Institute - University of Oxford, http://www.griffith.ox.ac.uk/gri/carter/135e.html (accessed 2018-1-31).

5 Crivellaro, A.; Schweingruber, F. H., Atlas of Wood, Bark and Pith Anatomy of Eastern Mediterranean Trees and Shrubs with Special Focus on Cyprus, Springer-Verlag, Berlin (2013).

6 Wheeler, E. A.; Baas, P.; Gasson, P. E., 'IAWA list of microscopic features for hardwood identification', IAWA Bulletin 10(3) (1989) 219-332.

7 Orsini, S.; Ribechini, E.; Modugno, F.; Klügl, J.; Di Pietro, G.; Colombini, M., 'Micro morphological and chemical elucidation of the degradation mechanisms of birch bark archaeological artefacts', Heritage Science 3 (2015) 2, https:// doi.org/10.1186/s40494-015-0032-7.

8 Angyalossy, V.; Pace M. R.; Baas. P., 'IAWA list of microscopic bark features', IAWA Journal 37(4) (2016) 517-615, https:// doi.org/10.1163/22941932-20160151.

9 Derrik, R. M.; Stulik, D.; Landy, M. J., Infrared Spectroscopy in Conservation Science, The Getty Conservation Institute, Los Angeles (1999).

10 Nabil, E.; Abdallah, M.; Abdrabou, A., 'An axial rotation device for documenting King Tutankhamun's decorated sticks', poster, documentation group, in 18th Triennial Conference, Copenhagen, 4-8 September 2017. Linking Past and Future. Preprints, ed. J.Brigland, ICOM-CC, Paris (2017).

11 Gänsicke, S., 'The conservation of decorated organic Egyptian surfaces: a literature review', in Decorated Surfaces on Ancient Egyptian Objects. Technology, Deterioration and Conservation, ed. J. Dawson, C. Rozeik \& M. M. Wright, Archetype Publications, London (2010) 67-77.

12 Gale, R.; Gasson, P.; Hepper, N., 'Wood', in Ancient Egyptian Materials and Technology, ed. T. Nicholson \& I. Shaw, Cambridge University Press, Cambridge (2000) 334-371.

13 Cartwright, C. R.; Ward, C.; Tubb, J.; Delaunay, H., 'The middle bronze age furniture from Tomb P19 at Jericho: wood identification and conservation challenges', The British Museum Technical Research Bulletin 3 (2009) 111-120. 
14 Waly, M. N., 'Identified wood specimens from Tutankhamun funerary furniture', Taeckholmia 16 61-74 (1996).

15 Lucas, A.; Harris, J. R., Ancient Egyptian Materials and Industries, 4th ed., Edward Arnold, London (1962).

16 Croft, S.; Mathewes, R. W., 'Barking up the right tree: Understanding birch bark artifacts from the Canadian Plateau, British Columbia', BC Studies 16(180) (2013) 180122.

17 Modugno, F.; Ribechini, E.; Colombini, M. P., 'Chemical study of triterpenoid resinous materials in archaeological findings by means of direct exposure electron ionisation mass spectrometry and gas chromatography/mass spectrometry', Rapid Commun Mass Spectrom 20(11) (2006) 1787-1800, https://doi.org/10.1002/rcm.2507.

18 Rifai, M. M.; El Hadidi, N. M. N., 'Investigation and analysis of three gilded wood samples from the tomb of Tutankhamun, in Decorated Surfaces on Ancient Egyptian Objects. Technology, Deterioration and Conservation, ed. J. Dawson, C. Rozeik \& M. M. Wright, Archetype Publications, London (2010) 16-24.

19 Hatchfield, P.; Newman, R., 'Ancient Egyptian gilding methods', in Gilded Wood Conservation and History, ed. D. Bigelow, E.Cornu, G. Landre \& C. van Home, Sound View Press, Madison CT (1991) 291-299.

20 Darque-Ceretti , E. D.; Felder. E.; Aucouturier, M. 'Foil and leaf gilding on cultural artifacts: forming and adhesion', Revista Matéria 16(1)) 2011) 540-559, https://doi. org/10.1590/s1517-70762011000100002.

21 Colinart, S., 'Analysis of inorganic yellow colour in ancient Egyptian painting', in Colour and Painting in Ancient Egypt, ed. W.V. Davies, British Museum Press, London (2001) 1-4.

22 James, T. G. H., 'Gold technology in ancient Egypt: mastery of metal working methods', Gold Bulletin 5(2) (1972) 38-42, https://doi.org/10.1007/bf03215160.

23 Tissot, I.; Troalen, L. G.; Manso, M.; Ponting, M.; Radtke, M.; Reinholz, U.; Barreiros, M. A.; Shaw, I.; Carvalho, M. L.; Guerra M. F., 'A multi-analytical approach to gold in Ancient Egypt: Studies on provenance and corrosion', Spectrochimica Acta Part B 108 (2015) 75-82, https://doi.org/10.1016/j. sab.2015.03.012.

24 Ismail, Y.; Abdrabou, A.; Abdallah, M., 'A non-destructive analytical study and the conservation processes of Pharaoh Tutankhamun's painted boat model', International Journal of Conservation Science 7(1) (2016) 15-28.

25 Gilberg, M., 'Alfred Lucas: Egypt's Sherlock Holmes', Journal of the American Institute for Conservation 36(1) (1997) 31-48, https://doi.org/10.1179/019713697806113620.

26 Abdrabou, A.; Abdallah M.; Kamal, H. M., 'Scientific investigation by technical photography, OM, ESEM, XRF, XRD and FTIR of an ancient Egyptian polychrome wooden coffin', Conservar Património 26 (2017) 51-63, https://doi. org/10.14568/cp2017008.

27 Bracci, S.; Caruso, O.; Galeotti, M.; Iannaccone, R.; Magrini, D.; Picchi, D.; Pinna, D.; Porcinai, S., 'Multidisciplinary approach for the study of an Egyptian coffin (late 22nd/ early 25th dynasty): combining imaging and spectroscopic techniques', Spectrochimica Acta Part A 145 (2015) 511-522, https://doi. org/10.1016/j.saa.2015.02.052.

28 Edreira, M. C.; Feliu, M. J.; Fernández-Lorenzo, C. F.; Martín, J., 'Spectroscopic study of Egyptian blue mixed with other pigments', Helvetica Chimica Acta 86 (2003) 29-49, https:// doi. org/10.1002/hlca.200390017.

29 Afifi, H.; AbdEl Fatah, M. A., 'Analytical study of ground painting layers and conservation processes of an Egyptian painted coffin', Journal of Life Sciences 5 (2011) 661-669.

30 Newman, R.; Halpine, M. S., 'The binding media of ancient Egyptian painting, in Colour and Painting in Ancient Egypt, ed. W. V. Davies, British Museum Press, London (2001) 2232 .

Conservar Património 30 (2019)
31 Serpico, M.; White, R., 'The use and identification of varnish on New Kingdom funerary equipment', in Colour and Painting in Ancient Egypt, ed. W. V. Davies, British Museum Press, London (2001) 33-42.

32 Kariya, H.; Bruno, L.; Godfrey, J.; March, T., 'Treatment of Dynasty 18 painted coffin, 37.47E a-e (Abbott collection 405A)', in Decorated Surfaces on Ancient Egyptian Objects. Technology, Deterioration and Conservation, ed. J. Dawson, C. Rozeik \& M. M. Wright, Archetype Publications, London (2010) 97-105.

33 Modugno, F.; Ribechini, E., 'GC/MS in the Characterisation of Resinous Materials', in Organic Mass Spectrometry in Art and Archaeology, ed. M. P. Colombini \& F. Modugno, John Wiley \& Sons, Chichester (2009) 215-235, https://doi. org/10.1002/9780470741917.ch8.

34 Bonizzoni, L.; Bruni, S.; Guglielmi, V.; Milazzo, M.; Neri, O., 'Field and laboratory multi-technique analysis of pigments and organic painting media from an Egyptian coffin (26th dynasty)', Archaeometry 53(6) (2011) 1212-1230, https://doi. org/10.1111/j.1475-4754.2011.00592.x.

35 Brecoulaki, H.; Fiorin, E.; Vigato. P. A., 'The funerary klinai of tomb 1 Amphipolis and a sarcophagus from ancient Tragilos, eastern Macedonia: a physico-chemical investigation on the painting materials', Journal of Cultural Heritage 7(4) (2016) 301-311, https://doi.org/10.1016/j.culher.2006.06.005.

36 Stein, R. A.; Lacounra, P., 'Observations on the preparation layers found on ancient Egyptian decorated coffins in the Michael C. Carlos Museum', in Decorated Surfaces on Ancient Egyptian Objects. Technology, Deterioration and Conservation, ed. J. Dawson, C. Rozeik \& M. M. Wright, Archetype Publications, London (2010) 3-8.

Received: 2017-5-27

Revised: 2017-12-1

Accepted: $2018-1-25$

Online: $2018-3-3$

This work is licensed under the Creative Commons Attribution-NonCommercial-NoDerivatives 4.0 International License. To view a copy of this license, visit http://creativecommons.org/licenses/by-nc-nd/4.0/deed.en. 